\title{
ANALISIS KESEHATAN MASYARAKAT BERDASARKAN RUANG LINGKUP KEPENDUDUKAN DAN KETENAGAKERJAAN DI KELURAHAN PEGIRIAN KECAMATAN SEMAMPIR KOTA SURABAYA
}

\author{
Nuria $^{1}$, Yuly Sulistyorini ${ }^{2}$ \\ ${ }^{1,2}$ Departemen Biostatistika dan Kependudukan \\ Fakultas Kesehatan Masyarakat Universitas Airlangga \\ Jl. Mulyorejo Kampus C Unair Surabaya 60115 \\ Alamat korespondensi: Nuria \\ E-mail: nuria-2016@fkm.unair.ac.id
}

\begin{abstract}
WHO (1947) defined health as a perfect condition both physically, mentally and socially and not only free from disease. The socio-economic aspect states the meaning of health if the community is able to advance its life by learning, working, or interacting with its surroundings. Public health in terms of socio-economic aspects can be seen from the conditions of population and employment. Through these two things, it can be seen the level of community welfare that can support the achievement of public health. Therefore, it is necessary to analyze population and employment conditions in Pegirian Village. This study will make it easier to carry out healthoriented development planning in order to achieve public health. This research is descriptive research with cross sectional approach. Research was conducted at $R T 06 R W 02$ Pegirian Village. Research was done at January 2018. This research was using secondary data from field work practices report of student FKM UNAIR 2018. Age data, gender, education, job, and tribe were used in this research. The results showed that the male population was $52.63 \%$. The population aged 15-64 years was $70.18 \%$. As many as $93.86 \%$ of the population was Madura Tribe. The percentage of the population that works and has the last primary education level or less was $68.29 \%$. The population generally worked at $73.68 \%$. Work force was $39.47 \%$. LFPR was $53.57 \%$ and open unemployment rate was $8.89 \%$. Public health conditions from the scope of population and employment in RT 06 $R W 02$ Pegirian Village Semampir Subdistrict are not good enough. Although, the population of productive age is high, the LFPR is still low. In addition, the level of education is still low so the quality of labor is also low.
\end{abstract}

Keywords: public health, population, employment

\begin{abstract}
ABSTRAK
WHO (1947) mengartikan kesehatan sebagai keadaan sempurna baik secara fisik, mental dan sosial serta tidak hanya bebas dari penyakit. Aspek sosial ekonomi menyatakan arti sehat apabila masyarakat mampu memajukan kehidupannya dengan belajar, bekerja, ataupun berinteraksi dengan sekitarnya. Kesehatan masyarakat dari segi sosial ekonomi dapat dilihat dari kondisi kependudukan dan ketenagakerjaan. Melalui dua hal tersebut dapat dilihat tingkat kesejahteraan masyarakat yang dapat mendukung tercapainya kesehatan masyarakat. Oleh karena itu, perlu dilakukan analisis kondisi kependudukan dan ketenagakerjaan di Kelurahan Pegirian. Kajian ini akan mempermudah dalam melakukan perencanaan pembangunan yang berwawasan kesehatan demi tercapainya kesehatan masyarakat. Penelitian ini merupakan penelitian deskriptif dengan pendekatan cross sectional. Penelitian dilakukan di wilayah RT 06 RW 02 Kelurahan Pegirian. Penelitian dilakukan pada Januari 2018. Data penelitian menggunakan data sekunder dari Laporan Praktik Kerja Lapangan (PKL) Mahasiswa FKM UNAIR tahun 2018. Data tersebut merupakan data karakteristik demografi penduduk yang meliputi data usia, jenis kelamin, pendidikan, pekerjaan, dan suku. Hasil penelitian menunjukkan penduduk laki-laki sebesar 52,63\%. Penduduk usia 15-64 tahun sebesar 70,18\%. Sebesar 93,86\% penduduk merupakan keturunan Suku Madura. Persentase penduduk yang bekerja dan memiliki tingkat pendidikan terakhir SD atau kurang adalah $68,29 \%$. Penduduk usia kerja sebesar 73,68\%. Angkatan kerja sebesar 39,47\%. TPAK sebesar 53,57\% dan TPT sebesar $8,89 \%$. Kondisi kesehatan masyarakat dari ruang lingkup kependudukan dan ketenagakerjaan di RT 06 RW 02 Kelurahan pegirian Kecamatan Semampir belum cukup baik. Meskipun, penduduk usia produktif tinggi, tetapi TPAK masih rendah. Selain itu, tingkat pendidikan yang masih rendah sehingga kualitas tenaga kerja juga rendah.
\end{abstract}

Kata kunci: kesehatan masyarakat, kependudukan, ketenagakerjaan 


\section{PENDAHULUAN}

World Health Organization (WHO, 1947) mengartikan kesehatan sebagai suatu keadaan yang sempurna baik secara fisik, mental dan sosial serta tidak hanya bebas dari penyakit. Sehat secara mental (kesehatan jiwa) adalah satu kondisi yang memungkinkan perkembangan fisik, intelektual dan emosional yang optimal dari seseorang dan perkembangan itu berjalan selaras dengan keadaan orang lain. Sehat secara sosial adalah perikehidupan seseorang dalam masyarakat yang diartikan bahwa seseorang mempunyai cukup kemampuan untuk memelihara dan memajukan kehidupannya sendiri dan kehidupan keluarga sehingga memungkinkan untuk bekerja, beristirahat dan menikmati liburan (Eliana \& Sri, 2016).

Berdasarkan dua pengertian kesehatan tersebut, dapat disarikan bahwa kesehatan ada empat dimensi, yaitu fisik (badan), mental (jiwa), sosial dan ekonomi yang saling mempengaruhi dalam mewujudkan tingkat kesehatan pada seseorang, kelompok, atau masyarakat. Oleh karena itu, kesehatan bersifat holistik atau menyeluruh, tidak hanya memandang kesehatan dari segi fisik saja (Eliana \& Sri, 2016).

Kesehatan masyarakat adalah aplikasi terpadu antara ilmu kedokteran, sanitasi, dan ilmu sosial dalam mencegah penyakit yang terjadi di masyarakat. Kesehatan masyarakat meliputi 7 ruang lingkup keilmuan. Salah satunya adalah ruang lingkup kependudukan yang dapat menilai tingkat kesehatan masyarakat dari aspek sosial dan ekonomi. Aspek sosial ekonomi menyatakan arti sehat apabila seseorang, keluarga, atau masyarakat mampu memajukan kehidupannya dengan belajar, bekerja, ataupun berinteraksi dengan masyarakat sekitarnya (Eliana \& Sri, 2016).

Kesehatan masyarakat dari segi sosial ekonomi dapat dilihat dari kondisi kependudukan dan ketenagakerjaan. Melalui kondisi kependudukan dan ketenagakerjaan dapat dilihat tingkat kesejahteraan masyarakat yang dapat mendukung tercapainya kesehatan masyarakat.

Gambaran kependudukan Kota Surabaya berdasarkan hasil Sensus Penduduk tahun 2010 adalah sebesar $7,38 \%$ penduduk Jawa Timur terdistribusi di Kota Surabaya, yaitu sejumlah 2.765.487 jiwa. Luas wilayah Kota Surabaya sekitar $350,54 \mathrm{~km}^{2}$ sehingga termasuk kota yang padat penduduk. Sex ratio sebesar 98,1. Jumlah kelahiran pada tahun 2016 adalah sebesar 31.572 kelahiran. Sedangkan, jumlah kematian sebesar 20.304 kematian. Pertumbuhan penduduk Kota surabaya sebesar 0,63\% dari hasil Sensus Penduduk tahun 2000 (BPS Kota Surabaya, 2017c).

Kondisi ketenagakerjaan Kota Surabaya adalah penduduk usia kerja (usia 15 tahun atau lebih) sebesar 2.254.188 orang. Sebesar 1.495.837 adalah Angkatan Kerja (AK), sedangkan sisanya adalah Bukan Angkatan Kerja (BAK). Sejumlah 89.479 orang yang termasuk angkatan kerja merupakan pengangguran. Besarnya TPAK adalah $66,36 \%$ dan Tingkat Pengangguran Terbuka (TPT) sebesar 5,98\%. Terjadi kenaikan jumlah angkatan kerja sebesar 1,89\% atau sekitar 33 ribu orang. Peningkatan dilihat dari jumlah angkatan kerja pada bulan Agustus 2015 sebesar 1,47 juta orang menjadi 1,5 juta orang pada Agustus 2017. Peningkatan tersebut sejalan dengan peningkatan Tingkat Partisipasi Angkatan Kerja (TPAK) Kota Surabaya yang menjadi 66,67\% pada Agustus 2017. Besarnya peningkatan adalah 0,26\% dari Agustus 2015 (BPS Kota Surabaya, 2017a).

Kecamatan Semampir termasuk ke dalam wilayah geografis Kota Surabaya, yaitu wilayah Surabaya Utara. Kecamatan Semampir memiliki luas wilayah $\pm 6,65 \mathrm{~km}^{2}$. Wilayah Kecamatan Semampir terbagi menjadi 5 kelurahan, yaitu Kelurahan Ampel, Sidotopo, Pegirian, Wonokusumo, dan Ujung. Jumlah penduduk total Kecamatan Semampir pada tahun 2016 adalah 180.613 jiwa. Kepadatan penduduk adalah $29.416 \mathrm{jiwa} / \mathrm{km}^{2}$ (BPS Kota Surabaya, 2017b).

Kehidupan ekonomi penduduk Kecamatan Semampir didominasi oleh sektor industri, baik dalam skala besar, sedang, maupun kecil. Contoh industri skala besar dan sedang yang ada di Kecamatan Semampir adalah industri mesin dan kendaraan bermotor. Terdapat 2 industri skala besar dan sedang di Kecamatan Semampir. Kedua industri tersebut cukup banyak memiliki tenaga kerja, masing-masing sejumlah 264 dan 453 tenaga kerja. Artinya, industri tersebut cukup banyak memberikan kesempatan kerja bagi penduduk Kecamatan Semampir. Sedangkan, industri skala kecil yang ada di Kecamatan Semampir adalah industri makanan dan minuman, tekstil, pakaian jadi, furniture, daur ulang, dan lainlain. Industri skala kecil juga cukup banyak 
menyerap tenaga kerja karena jumlahnya yang banyak, yaitu total 570 tenaga kerja. Terdapat 82 industri kecil di Kecamatan Semampir. Industri skala kecil yang paling banyak adalah industri makanan minuman, yaitu sebanyak 24 (BPS Kota Surabaya, 2017b).

Kelurahan Pegirian merupakan salah satu kelurahan di Kecamatan Semampir dengan luas wilayah $\pm 0,40 \mathrm{~km}^{2}$. Jumlah penduduk di Kelurahan Pegirian adalah sebesar 31.874 jiwa. Kepadatan penduduknya adalah 79.685 jiwa/ $\mathrm{km}^{2}$ (BPS Kota Surabaya, 2017b). Padatnya penduduk menjadi penyebab timbulnya berbagai masalah terkait kependudukan dan ketenagakerjaan, seperti rendahnya tingkat pendidikan dan tingginya tingkat pengangguran. Kepadatan penduduk menyebabkan besarnya jumlah pencari kerja lebih besar daripada lapangan kerja yang tersedia. Akibatnya jumlah pengangguran meningkat. Hal ini berdampak pada menurunnya kualitas sosial, seperti banyaknya tuna wisma, pengemis, kriminalitas, dan lainlain (Christiani, et.al., 2014).

Pemerintah telah mengupayakan berbagai cara untuk mengatasi masalah kepadatan penduduk, seperti program KB dan sosialisasi tunda nikah dini. Masalah ketenagakerjaan pun tidak luput dari perhatian Pemerintah. Pemerintah telah berupaya untuk membuka lapangan pekerjaan untuk mengurangi jumlah pengangguran. Akan tetapi, sampai saat ini upaya-upaya tersebut nampaknya belum banyak menyelesaikan permasalahan kependudukan maupun ketenagakerjaan (Christiani, et.al., 2014).

Kelurahan Pegirian harus melakukan upaya untuk mengatasi berbagai permasalahan yang muncul sebagai akibat padatnya penduduk. Perlu dilakukan analisis kondisi kependudukan dan ketenagakerjaan di Kelurahan Pegirian. Hal ini penting untuk dilakukan karena penduduk dan tenaga kerja (Sumber Daya Manusia/SDM) dibutuhkan untuk menopang pembangunan. SDM yang memadai akan mempercepat terlaksananya rencana pembangunan wilayah, termasuk di dalamnya adalah pembangunan kesehatan masyarakat. SDM adalah sumber daya utama pada proses pembangunan. SDM yang melimpah juga akan mempercepat perkembangan ekonomi sehingga membentuk perekonomian yang lebih baik. Sebaliknya, tanpa SDM yang adekuat akan menyebabkan aktivitas perekonomian menjadi terhambat dan pertumbuhannya melambat (Junaidi \& Zulfanetti, 2016).

Data mengenai kependudukan dan ketenagakerjaan memegang peranan penting dalam proses perencanaan pembangunan, termasuk dalam pembangunan kesehatan. Semakin lengkap dan tepat, maka rencana pembangunan akan semakin mudah tersusun. Jadi, dapat dikatakan bahwa faktor kependudukan dan ketenagakerjaan merupakan unsur terpenting pada proses pembangunan, termasuk pembangunan kesehatan (Syaadah, 2014).

Berdasarkan latar belakang tersebut, maka perlu dilakukan analisis kondisi kependudukan dan ketenagakerjaan di Kecamatan Semampir. Kajian ini akan mempermudah dalam melakukan perencanaan pembangunan yang berwawasan kesehatan demi tercapainya kesehatan masyarakat.

\section{METODE PENELITIAN}

Penelitian ini merupakan penelitian observasional. Penelitian dilakukan di wilayah RT 06 RW 02 Kelurahan Pegirian Kecamatan Semampir Kota Surabaya. Penelitian dilakukan pada bulan Januari 2018. Data yang digunakan merupakan data sekunder dari kegiatan Praktik Kerja Lapangan (PKL) Mahasiswa Fakultas Kesehatan Masyarakat Universitas Airlangga.

Data yang digunakan dalam penelitian merupakan data karakteristik demografi penduduk yang meliputi data usia, jenis kelamin, suku, pendidikan, dan pekerjaan. Data tersebut kemudian diolah menggunakan aplikasi komputer dan dianalisis secara deskriptif.

\section{HASIL PENELITIAN}

\section{Karakteristik Penduduk}

Data mengenai karakteristik penduduk dapat dilihat pada tabel 1 yang menunjukkan bahwa terdapat $52,63 \%$ penduduk berjenis kelamin laki-laki. Berdasarkan usia sebagian besar penduduk merupakan penduduk usia produktif antara 15-64 tahun, yaitu sebesar $70,18 \%$. Mayoritas penduduk merupakan keturunan suku Madura, yaitu sebesar 93,86\%. Pendidikan terakhir yang ditempuh oleh mayoritas penduduk adalah Sekolah Dasar (SD), yaitu sebesar $44,74 \%$. 
Tabel 1. Karakteristik Penduduk RT 06 RW 02 Kelurahan Pegirian Tahun 2018

\begin{tabular}{lcc}
\hline Karakteristik & Jumlah & Persentase (\%) \\
\hline Jenis Kelamin & & \\
Laki-laki & 60 & 52,63 \\
Perempuan & 54 & 47,37 \\
\hline Usia (tahun) & & \\
$0-14$ & 31 & 27,19 \\
$15-64$ & 80 & 70,18 \\
$>65$ & 3 & 2,63 \\
\hline Suku & & \\
Madura & 107 & 93,86 \\
Jawa & 7 & 6,14 \\
\hline Tingkat Pendidikan & & \\
Tidak sekolah & 17 & 14,91 \\
Belum sekolah & 19 & 16,67 \\
SD & 51 & 44,74 \\
SMP & 13 & 11,40 \\
SMA & 13 & 11,40 \\
PT & 1 & 0,88 \\
\hline
\end{tabular}

Sumber: Laporan PKL Mahasiswa FKM UNAIR Tahun 2018

\section{Karakteristik Ketenagakerjaan}

Karakteristik ketenagakerjan penduduk ditunjukkan tabel berikut.

Tabel 2. Karakteristik Ketenagakerjaan RT 06 RW 02 Kelurahan Pegirian Tahun 2018

\begin{tabular}{|c|c|c|}
\hline Karakteristik & Jumlah & $\begin{array}{c}\text { Persentase } \\
(\%)\end{array}$ \\
\hline $\begin{array}{l}\text { Penduduk usia } \\
\text { kerja }\end{array}$ & 84 & 73,68 \\
\hline Angkatan Kerja & 45 & 39,47 \\
\hline Bekerja & 41 & 35,97 \\
\hline Pengangguran & 4 & 3,51 \\
\hline $\begin{array}{l}\text { Bukan Angkatan } \\
\text { Kerja }\end{array}$ & 69 & 60,53 \\
\hline Sekolah & 29 & 25,44 \\
\hline $\begin{array}{l}\text { Mengurus Rumah } \\
\text { Tangga }\end{array}$ & 31 & 27,19 \\
\hline Lainnya & 9 & 7,90 \\
\hline TPAK & - & 53,57 \\
\hline TPT & - & 8,89 \\
\hline
\end{tabular}

Masing-masing karakteristik ketenagakerjaan yang disebutkan pada tabel 2 dihitung persentasenya berdasarkan total penduduk. Artinya jumlah penduduk pada masing-masing karakteristik dibandingkan dengan total penduduk sejumlah 114 dan dikalikan $100 \%$. Hasil perhitungan menunjukkan besarnya persentase penduduk usia kerja adalah $73,68 \%$.

Penduduk yang termasuk angkatan kerja adalah 39,47\%. Angkatan kerja terdiri dari penduduk bekerja dan pengangguran. Meskipun demikian, dalam perhitungan persentasenya, penduduk bekerja dan pengangguran dilakukan berdasarkan total populasi, bukan angkatan kerja. Sehingga menghasilkan besarnya persentase penduduk bekerja adalah $35,97 \%$ dan pengangguran sebesar $3,51 \%$.

Persentase penduduk bukan angkatan kerja sebesar 60,53\%. Penduduk bukan angkatan kerja terdiri atas anak sekolah, ibu rumah tangga, dan lain-lain. Persentase dari masing-masing karakteristik juga dilakukan berdasarkan total penduduk. Hasil perhitungan menunjukkan besarnya penduduk yang masih sekolah adalah 25,44\%, ibu rumah tangga adalah 27,19\%, dan lain-lain sebesar 7,90\%.

Tingkat Partisipasi Angkatan Kerja adalah perbandingan antara angkatan kerja dengan penduduk usia kerja dikali 100\%. Hasil perhitungan menunjukkan besarnya TPAK adalah 53,57\%. Sedangkan, Tingkat Pengangguran Terbuka (TPT) adalah perbandingan antara pengangguran dengan angkatan kerja dikali $100 \%$. Hasil perhitungan menunjukkan besarnya TPT adalah sebesar $8,89 \%$.

\section{Gambaran Tingkat Pendidikan dan Status Pengangguran Penduduk}

Berikut ini disajikan tabulasi silang antara tingkat pendidikan dan status pengangguran.

Tabel 3. Tingkat Pendidikan dan Status Pengangguran Penduduk RT 06 RW 02 Kelurahan Pegirian Tahun 2018

\begin{tabular}{lccccc}
\hline \multirow{2}{*}{$\begin{array}{c}\text { Status } \\
\text { Pengangguran }\end{array}$} & \multicolumn{4}{c}{ Tingkat Pendidikan } & \multirow{2}{*}{ Sotal } \\
\cline { 2 - 5 } & SMP & SMA & PT & \\
\hline Ya & 0 & 0 & 4 & 0 & 4 \\
$(\%)$ & $(0)$ & $(0)$ & $(100)$ & $(0)$ & $(100)$ \\
Tidak & 87 & 13 & 9 & 1 & 110 \\
$(\%)$ & $(79,1)$ & $(11,8)$ & $(8,2)$ & $(0,9)$ & $(100)$ \\
\hline \multicolumn{4}{c}{ Sumber: Laporan PKL Mahasiswa FKM UNAIR } \\
\multicolumn{5}{c}{ Tahun 2018 }
\end{tabular}


Tabel 3 menjelaskan bahwa penduduk yang merupakan pengangguran berjumlah 4 orang dan semuanya memiliki tingkat pendidikan terakhir SMA/sederajat.

\section{Gambaran Tingkat Pendidikan dan Status Bekerja Penduduk}

Berikut ini disajikan tabulasi silang antara tingkat pendidikan dan status bekerja.

Tabel 4. Tingkat Pendidikan dan Status Bekerja Penduduk RT 06 RW 02 Kelurahan Pegirian Tahun 2018

\begin{tabular}{lccccc}
\hline Status & \multicolumn{4}{c}{ Tingkat Pendidikan } & Total \\
\cline { 2 - 6 } Bekerja & SD & SMP & SMA & PT & \\
\hline Ya & 28 & 5 & 7 & 1 & 41 \\
$(\%)$ & $(68,3)$ & $(12,2)$ & $(17,1)$ & $(2,4)$ & $(100)$ \\
Tidak & 59 & 8 & 6 & 0 & 73 \\
$(\%)$ & $(80,8)$ & $(11,0)$ & $(8,2)$ & $(0)$ & $(100)$ \\
\hline
\end{tabular}

Tabel 4 menunjukkan bahwa 68,3\% penduduk yang bekerja merupakan penduduk dengan tingkat pendidikan terakhir $\mathrm{SD} /$ sederajat atau lebih rendah.

\section{PEMBAHASAN}

\section{Karakteristik Penduduk}

\section{Jenis Kelamin}

Penduduk laki-laki lebih banyak daripada perempuan dengan persentase $52,63 \%$. Apabila dilihat berdasarkan sex ratio, diperoleh sex ratio penduduk sebesar 111,11, artinya terdapat 111,11 penduduk laki-laki pada setiap 100 penduduk perempuan. Berdasarkan sudut pandang kependudukan, angka tersebut masih tergolong rasio yang normal.

Menurut sudut pandang ketenagakerjaan yang berkembang di masyarakat, terdapat perbedaan peran antara laki-laki dan perempuan. Masyarakat menganggap bahwa laki-laki adalah main/primary breadwinner dan perempuan adalah secondary breadwinner. Budaya ini dikenal sebagai budaya patriarkhi (Yusrini, 2017). Budaya tersebut menyebabkan terjadinya perbedaan peran dalam masyarakat. Laki-laki banyak berperan dalam kegiatan ekonomi dan kemasyarakatan (publikproduktif). Sedangkan perempuan berperan dalam ranah domestik-reproduktif (Rahayuningsih, 2013).
Ada berbagai faktor yang mempengaruhi kurangnya peran perempuan dalam kegiatan ekonomi atau dunia kerja. Dua diantaranya adalah faktor pendidikan dan status perkawinan. Budaya patriarkhi memandang bahwa anak laki-laki dianggap lebih penting daripada perempuan. Oleh karena itu, pendidikan pada laki-laki akan lebih diutamakan daripada perempuan. Akibatnya tingkat pendidikan pada perempuan rendah (Yusrini, 2017). Keterbatasan perempuan dalam pendidikan berakibat pada kurangnya peran wanita dalam dunia kerja. Hal tersebut terjadi karena saat ini pekerjaan sektor formal akan meminta kualifikasi tenaga kerja yang tinggi. Kalaupun dapat memasuki pekerjaan pada sektor formal, seseorang dengan pendidikan rendah akan menempati posisi terbawah dengan upah yang minimal dan terbatasnya prospek pengembangan karir (ILO, 2015).

Faktor status perkawinan juga mempengaruhi peran perempuan dalam dunia kerja. Tenaga kerja perempuan biasanya sudah bekerja sebelum berumah tangga. Akan tetapi, beban perempuan akan bertambah ketika mereka sudah menikah dan memiliki anak. Perempuan akan memiliki peran ganda apabila bekerja sekaligus mengurus rumah tangga. Peran ganda ini akhirnya menyebabkan konflik bagi seorang perempuan yang bekerja (Rahayuningsih, 2013). Peran ganda menyebabkan kurangnya keterlibatan perempuan di dunia kerja dibandingkan lakilaki. Kurangnya keterlibatan perempuan di dalam dunia kerja menyebabkan TPAK perempuan lebih rendah daripada laki-laki. Badan Pusat Statistik (BPS) Provinsi Jawa Timur menunjukkan bahwa TPAK perempuan sebesar 52,06\%, sedangkan TPAK laki-laki sebesar $80,89 \%$ (BPS Provinsi Jawa Timur, 2017).

Telah dijelaskan di awal bahwa penduduk RT 06 RW 02 Kelurahan Pegirian terdiri dari laki-laki dan perempuan yang hampir seimbang. Oleh karena itu diharapkan kedua kelompok penduduk dapat sama-sama terlibat secara ekonomi untuk meningkatkan pendapatan keluarga. Pendapatan keluarga yang cukup diharapkan dapat mendukung dalam upaya peningkatan status kesehatan keluarga.

Usia 
Jumlah penduduk usia 0-15 tahun sebesar 27,19\%, penduduk usia 15-64 tahun sebesar $70,18 \%$, dan penduduk usia 65 tahun atau lebih sebesar 2,63\%. Apabila dilihat dari komposisi tersebut, dapat dikatakan bahwa struktur penduduk adalah struktur penduduk muda. Struktur penduduk muda menunjukkan bahwa angka kelahiran tinggi dan angka kematian penduduk rendah. Wilayah dengan struktur penduduk muda diharapkan mampu melakukan investasi di bidang pendidikan dan kesehatan. Hal tersebut akan bermanfaat bagi produktivitas tenaga kerja serta menentukan kesejahteraan penduduk lansia pada waktu mendatang (Salim, et.al., 2015).

Menurut komposisi usia penduduk diperoleh angka dependency ratio sebesar $42,5 \%$. Angka tersebut menunjukkan bahwa 100 orang yang berusia produktif menanggung beban sebesar 42,5 orang yang belum produktif atau tidak produktif lagi. Ini merupakan angka yang cukup baik karena penduduk usia produktif lebih besar dari penduduk usia non produktif. Sedikitnya penduduk usia tidak produktif yang harus ditanggung oleh penduduk usia produktif memberikan kesempatan bagi penduduk untuk dapat menabung (saving). Tabungan akan memungkinkan penduduk untuk melakukan investasi tambahan sehingga perekonomian dapat tumbuh lebih baik. Akan tetapi, perlu diperhatikan bahwa dalam definisi dependency ratio, ukuran ketergantungan hanya dilihat berdasarkan usia. Sedangkan, pada kondisi real, tidak semua yang termasuk ke dalam usia produktif adalah seseorang yang secara real produktif secara ekonomi. Sebagai contoh adalah penduduk yang termasuk pelajar dan ibu rumah tangga. Mereka termasuk ke dalam kelompok usia produktif, tetapi mereka tidak produktif secara ekonomi. Oleh karena itu, rasio ketergantungan penduduk harus dilihat sebagai konsep yang dinamis dengan batasan usia yang bisa berubah seiring perubahan kualitas penduduk (Salim, et.al., 2015).

\section{Suku}

Sebesar 93,86\% penduduk RT 06 RW 02 Kelurahan Pegirian merupakan keturunan Suku Madura. Merantau sudah menjadi budaya bagi orang Madura. Orang madura menyadari bahwa pulaunya sempit dan tidak subur. Selain itu, sumber daya alam juga terbatas sehingga membatasi ruang gerak orang Madura dalam mencari pekerjaan. Oleh karena itu, orang Madura akan merantau untuk memperbaiki nasib dan ekonominya (Faraby, 2014). Hal tersebut merupakan penyebab tingginya persentase penduduk Madura di Wilayah Kelurahan Pegirian.

Orang Madura perantauan merupakan pelaku ekonomi yang sangat berani berkompetisi secara terbuka. Selain pemberani, mereka juga memiliki etos kerja yang tinggi. Bagi mereka, etos kerja berkaitan dengan harga diri. Mereka memiliki prinsip lebih baik bekerja (usaha) sendiri meskipun hanya kecilkecilan, daripada harus bekerja ikut orang lain. Dalam menjalankan usahanya, meraka melakukannya dengan rasa percaya diri dan tidak malu atau takut apabila mengalami kerugian (Faraby, 2014).

\section{Pendidikan}

Berdasarkan tingkat pendidikan, persentase pendidikan terbesar adalah SD, yaitu $44,74 \%$. Selain itu, persentase penduduk yang tidak sekolah juga cukup besar yaitu, $14,91 \%$. Pendidikan termasuk hal yang berperan penting untuk mendorong peningkatan produktivitas (Todaro \& Smith, 2015). Pendidikan akan membentuk pengetahuan dan keterampilan, baik teknis ataupun kognitif, sehingga dapat meningkatkan produktivitas. Secara empiris, studi yang dilakukan oleh Sukmana (2013) menunjukkan tingkat pendidikan berpengaruh terhadap tingkat produktivitas.

Tingkat pendidikan berpengaruh dalam proses input tenaga kerja di suatu perusahaan. Pernyataan tersebut sesuai dengan hasil penelitian dari Kadafi (2013) yang menyatakan bahwa variabel pendidikan mempunyai pengaruh positif terhadap penyerapan tenaga kerja. Lebih tinggi tingkat pendidikan, maka akan lebih tinggi kemungkinan untuk diterima kerja.

Tingkat pendidikan juga mempengaruhi penempatan posisi kerja. Ini terbukti pada penelitian yang dilakukan oleh Budiarti (2014) bahwa tingkat pendidikan berkorelasi positif terhadap penempatan kerja karyawan. Lebih tinggi jenjang pendidikan maka lebih tinggi posisi kerja yang diterima karyawan. Sebaliknya, lebih rendah pendidikan, maka lebih rendah juga posisi kerjanya.

Tingkat pendidikan juga berpengaruh terhadap perilaku kesehatan. Pendidikan yang 
rendah menjadikan masyarakat sulit untuk memahami akan pentingnya berperilaku sehat. Oleh karena itu, masyarakat dengan tingkat pendidikan rendah cenderung tidak peduli dengan kesehatan dan perilaku sehat sebagai upaya peningkatan derajat kesehatan mereka.

\section{Karakteristik Ketenagakerjaan}

\section{Penduduk Usia Kerja}

Penduduk usia kerja adalah penduduk yang berusia 15 tahun atau lebih (BPS Kota Surabaya, 2017a). Penduduk usia kerja merupakan bagian dari populasi yang dapat menggambarkan sumber tenaga kerja. Ukuran dan komposisi penduduk usia kerja merupakan sesuatu yang penting untuk mendukung ketenagakerjaan di suatu wilayah (Center for Labor Market Studies Northeastern University, 2008).

Berdasarkan ukurannya, sebesar $73,68 \%$ penduduk termasuk ke dalam kelompok penduduk usia kerja. Hal tersebut berarti bahwa ukuran penduduk usia kerja cukup besar. Akan tetapi, perlu dilihat dari segi komposisinya karena penduduk yang termasuk ke dalam kelompok penduduk usia kerja belum tentu secara real mereka bekerja. Sebagai contoh adalah penduduk yang termasuk pelajar dan ibu rumah tangga. Mereka termasuk ke dalam kelompok usia kerja, tetapi tidak produktif secara ekonomi. Selain itu, juga pada kelompok lansia yang sudah tidak dapat bekerja lagi (Salim, et.al., 2015).

Apabila komposisi anak yang masih sekolah, ibu rumah tangga, dan juga lansia lebih besar, maka tingkat partisipasi angkatan kerja juga akan rendah (Salim, et.al., 2015). Selain itu, besarnya jumlah penduduk usia produktif juga dapat menimbulkan suatu permasalahan. Itu terjadi apabila besarnya jumlah penduduk usia kerja tidak diimbangi ketersediaan lapangan pekerjaan. Dampaknya adalah besarnya tingkat pengangguran terbuka (ILO, 2015).

\section{Angkatan Kerja}

Besarnya penduduk yang merupakan angkatan kerja adalah $39,47 \%$. Penduduk yang termasuk angkatan kerja adalah penduduk yang berusia 15 tahun atau lebih yang bekerja, memiliki pekerjaan namun sementara tidak bekerja, serta pengangguran. Memiliki pekerjaan tetapi sementara tidak bekerja adalah seseorang yang memiliki pekerjaan, tetapi dalam waktu seminggu yang lalu tidak bekerja karena berbagai hal, seperti sakit, cuti, menunggu panenan, mogok, dan sebagainya (BPS Kota Surabaya, 2017a).

Angkatan kerja terdiri dari penduduk yang bekerja dan menganggur. Penduduk yang bekerja adalah $35,97 \%$. Ini merupakan bagian yang kecil apabila dibandingkan dengan persentase penduduk usia kerja yang sebesar $73,68 \%$. Hal itu terjadi karena tidak semua penduduk yang termasuk penduduk usia kerja merupakan penduduk yang benar-benar bekerja (Salim, et.al., 2015).

Penduduk yang merupakan pengangguran cukup rendah, yaitu sebesar $3,51 \%$. Pengangguran merupakan angkatan kerja, tetapi belum bekerja atau sedang mencari kerja (BPS Kota Surabaya, 2017a). Mereka yang termasuk ke dalam kelompok pengangguran adalah penduduk yang baru menyelesaikan sekolah dan belum mendapat pekerjaan (Mustofani, et.al, 2018). Biasanya, pengangguran terjadi karena rendahnya tingkat pendidikan dan ketidaksesuaian keterampilan penduduk. Rendahnya tingkat pendidikan menyebabkan tidak terpenuhinya kualifikasi tenaga kerja yang diinginkan oleh perusahaan. Selain itu, ketidaksesuaian keterampilan juga menyebabkan perusahaan tidak mau menerima seorang tenaga kerja (ILO, 2015).

\section{Bukan Angkatan Kerja}

Penduduk yang termasuk bukan angkatan kerja adalah penduduk berusia 15 tahun atau lebih yang masih sekolah, mengurus rumah tangga atau melakukan kegiatan lain, di luar kegiatan pribadi. Penduduk bukan angkatan kerja sebesar $60,53 \%$. Hal ini berarti bahwa penduduk bukan angkatan kerja lebih besar dibandingkan penduduk angkatan kerja. Penduduk bukan angkatan kerja terdiri dari ibu rumah tangga sebesar $27,19 \%$, pelajar sebesar $25,44 \%$ dan lain-lain sebesar 7,90\%.

Pemberdayaan sebaiknya dilakukan bagi kelompok penduduk yang termasuk kelompok ibu rumah tangga. Hal tersebut perlu dilakukan untuk dapat meningkatkan besarnya penduduk angkatan kerja. Sedangkan, bagi penduduk yang termasuk kelompok pelajar harus dilakukan investasi pendidikan untuk dapat memperbaiki kondisi ketenagakerjaan di masa depan. Tanpa adanya intervensi yang efektif dalam bidang pendidikan, maka diperkirakan tidak akan ada perubahan yang signifikan di 
bidang ketenagakerjaan di masa depan (Adam, 2016).

\section{Tingkat Partisipasi Angkatan Kerja}

TPAK adalah jumlah angkatan kerja dibandingkan dengan penduduk usia kerja. Salah satu indikator yang bisa mengukur besarnya penyerapan tenaga kerja adalah TPAK. TPAK menyatakan besarnya penduduk usia $\geq 15$ tahun yang aktif melakukan kegiatan ekonomi pada suatu wilayah (BPS Kota Surabaya, 2017a). TPAK penduduk sebesar $53,57 \%$. Ini berarti bahwa hanya setengah dari penduduk usia kerja yang aktif secara ekonomi. Kembali lagi seperti bahasan pada angkatan kerja, bahwa mereka yang termasuk kelompok penduduk usia kerja, belum tentu secara real bekerja (Salim, et.al., 2015). Oleh karena itu, besarnya tingkat partisipasi angkatan kerja akan dipengaruhi oleh komposisi penduduk usia kerja (Center for Labor Market Studies Northeastern University, 2008). Besarnya penduduk usia sekolah, ibu rumah tangga, dan lansia merupakan penyebab rendahnya TPAK (Salim, et.al., 2015).

\section{Tingkat Pengangguran Terbuka}

TPT penduduk RT 06 RW 02 Kelurahan Pegirian adalah $8,89 \%$. TPT adalah jumlah pengangguran dibandingkan dengan jumlah penduduk angkatan kerja. Pengangguran adalah angkatan kerja yang belum bekerja atau sedang mencari kerja (BPS Kota Surabaya, 2017a). Berdasarkan Tabel 4, 100\% penduduk yang termasuk pengangguran adalah lulusan SMA atau sederajat. $75 \%$ penduduk yang termasuk pengangguran masih dalam proses mencari pekerjaan setelah lulus sekolah, sedangkan $25 \%$ menganggur karena menjaga orang tua yang sudah tua (Mustofani, et.al, 2018).

Pengangguran terjadi apabila jumlah pencari kerja lebih besar dibandingkan jumlah tenaga kerja yang dibutuhkan pasar. Pengangguran termasuk salah satu masalah dan beban pemerintah. Jumlah penduduk terus meningkat setiap tahunnya, tetapi kemampuan ekonomi, baik pemerintah maupun swasta tidak sebanding dengan kenaikan jumlah penduduk (Junaidi \& Zulfanetti, 2016).

Biasanya, pengangguran terjadi karena rendahnya tingkat pendidikan dan ketidaksesuaian keterampilan penduduk. Rendahnya tingkat pendidikan menyebabkan tidak terpenuhinya kualifikasi tenaga kerja yang diinginkan. Ketidaksesuaian keterampilan juga menyebabkan perusahaan tidak mau menerima seorang tenaga kerja (ILO, 2015).

\section{Gambaran Tingkat Pendidikan dan Status Pengangguran Penduduk}

Sebesar $100 \%$ penduduk yang merupakan pengangguran adalah penduduk dengan tingkat pendidikan terakhir SMA/sederajat. Apabila dilihat berdasarkan angka absolut, penduduk yang termasuk pengangguran hanya sebagian kecil, yaitu 4 dari 114 penduduk RT 06 RW 02 Kelurahan Pegirian atau sekitar 0,035\%. Meskipun demikian, bukan berarti 99,965\% sisanya merupakan penduduk bekerja. Di antara penduduk yang tidak termasuk kategori pengangguran adalah pelajar dan ibu rumah tangga, yaitu penduduk yang tidak termasuk angkatan kerja. Artinya, secara definisi mereka tidak termasuk kategori pengangguran, namun pada kenyataannya mereka tidak produktif secara ekonomi.

\section{Gambaran Tingkat Pendidikan dan Status Bekerja Penduduk}

Sebesar 68,3\% penduduk RT 06 RW 02 Kelurahan Pegirian yang bekerja merupakan penduduk dengan tingkat pendidikan SD atau lebih rendah. hal ini terjadi karena memang sebagian besar dari mereka merupakan lulusan SD atau lebih rendah. Berbekal tingkat pendidikan yang rendah, sebagian besar penduduk memilih bekerja sebagai pedagang. Selain sebagai pedagang, mereka bekerja sebagai buruh atau pekerja lepas, jenis-jenis pekerjaan yang tidak berorientasi pada tingkat pendidikan.

\section{SIMPULAN DAN SARAN}

\section{Simpulan}

Menurut sudut pandang kependudukan, besarnya penduduk usia produktif sebesar 70,18\% dengan dependency ratio (DR) sebesar $42,5 \%$ dapat dikatakan bahwa komposisi tersebut cukup baik sebagai modal pembangunan kesehatan. Akan tetapi, karena besarnya penduduk bekerja yang memiliki tingkat pendidikan terakhir SD atau lebih rendah cukup tinggi, yaitu sebesar 68,29\%, maka perlu dilakukan upaya perbaikan dalam bidang pendidikan. Seperti yang telah diketahui, pendidikan dapat mempengaruhi 
perilaku kesehatan yang akan mendukung upaya peningkatan kesehatan masyarakat.

Menurut sudut pandang ketenagakerjaan, penduduk usia kerja sebesar 73,68\%, akan tetapi persentase TPAK sebesar 53,57\%. Ini merupakan gambaran yang belum cukup baik terkait ketenagakerjaan. Meskipun, gambaran kesehatan dalam bidang sosial sudah dapat dikatakan cukup baik karena sudah lebih dari setengah penduduk produktif melakukan pekerjaan dan kegiatan sosial ekonomi yang menyiratkan kesehatan secara fisik dan mental.

Secara keseluruhan kondisi kesehatan masyarakat dari ruang lingkup kependudukan dan ketenagakerjaan di RT 06 RW 02 Kelurahan pegirian Kecamatan semampir belum cukup baik. Meskipun, penduduk usia produktif tinggi, tetapi TPAK masih rendah. Selain itu, tingkat pendidikan yang masih rendah sehingga kualitas tenaga kerja juga rendah.

\section{Saran}

Peneliti memberikan saran bagi pihak SKPD Kecamatan Semampir dan Kelurahan Pegirian khususnya untuk secara aktif memberikan informasi dan membantu proses pendaftaran bagi penduduknya untuk mengikuti Pelatihan Kerja Gratis yang difasilitasi oleh Dinas Tenaga Kerja (Disnaker) Kota Surabaya. Informasi yang diberikan dapat berupa pelatihan-pelatihan apa saja yang tersedia, siapa saja yang boleh mengikuti, dan apa saja persyaratan untuk mengikuti pelatihan tersebut. Setelah itu, pihak Kelurahan Pegirian membantu mendaftarkan penduduknya yang telah memenuhi syarat untuk memudahkan masyarakat yang kurang paham mengenai teknis pendaftaran. Hal ini bertujuan untuk meningkatkan kualitas Sumber Daya Manusia (SDM) penduduk Kelurahan Pegirian. Semakin baik kualitas SDM diharapkan dapat meningkatkan derajat kesehatan masyarakat di Kelurahan Pegirian.

\section{DAFTAR PUSTAKA}

Adam, L. 2016. Membangun Daya Saing Tenaga Kerja Indonesia melalui Peningkatan Produktivitas. Jurnal Kependudukan Indonesia, [e-journal] 11 (2): pp. 71-84.

BPS Kota Surabaya. 2017a. Keadaan Ketenagakerjaan Kota Surabaya, Agustus
2017. Surabaya: Badan Pusat Statistik Kota Surabaya.

BPS Kota Surabaya. 2017b. Kecamatan Semampir Dalam Angka 2017. Surabaya: Badan Pusat Statistik Kota Surabaya.

BPS Kota Surabaya. 2017c. Kota Surabaya Dalam Angka 2017. Surabaya: Badan Pusat Statistik Kota Surabaya.

BPS Provinsi Jawa Timur. 2017. Perempuan dan Laki-laki Provinsi Jawa Timur Tahun 2016. Surabaya: Badan Pusat Statistik Provinsi Jawa Timur.

Budiarti, N. 2014. Pengaruh Jenjang Pendidikan dan Pengalaman Kerja terhadap Persepsi Mengenai Penempatan Kerja di PT. Tiga Serangkai. Skripsi. Universitas Muhammadiyah Surakarta.

Center for Labor Market Studies Northeastern University. 2008. Total Population, Working-Age Population and The Labor Force of The North Central Massachusetts Workforce Area. Journal of Labor Market Developments in the North Central Massachusetts Workforce Area page 1-3. Northeastern University.

Christiani, C., Pratiwi, T., Bambang M. 2014. Analisis Dampak Kepadatan Penduduk Terhadap Kualitas Hidup Masyarakat Provinsi Jawa Tengah. Serat Acitya (Jurnal Ilmiah) UNTAG Semarang, [e-journal] 3 (1): pp. 102-114.

Eliana, Sri, S. 2016. Kesehatan Masyarakat. Jakarta: Kementerian Kesehatan Republik Indonesia.

Faraby, M.E. 2014. Etos Kerja Pedagang Etnis Madura di Pusat Grosir Surabaya ditinjau dariEtika Bisnis Islam. Jurnal Ekonomi Syariah Teori dan Terapan (JESTT), [ejournal] 1 (3): pp. 178-193.

ILO. 2015. Tren Tenga Kerja dan Sosial di Indonesia 2014-2015: Memperkuat Daya Saing dan Produktivitas melalui Pekerjaan Layak. Jakarta: ILO untuk Indonesia.

Junaidi, Zulfanetti. 2016. Analisis Kondisi dan Proyeksi Ketenagakerjaan di Provinsi Jambi. Jurnal Perspektif Pembiayaan dan Pembangunan Daerah, [e-journal] 3 (3): pp. 141-150.

Kadafi, M.F. 2013. Analisis Faktor yang Mempengaruhi Penyerapan Tenaga Kerja pada Industri Konveksi Kota Malang. Jurnal Ilmiah Mahasiswa FEB Universitas Brawijaya, [e-journal] 1 (2).

Mustofani, Nuria, Pramita, I.P.A., et.al. 2018. Laporan PKL Mahasiswa FKM Universitas 
Airlangga di Kelurahan Pegirian Kecamatan Semampir Kota Surabaya. Surabaya: Universitas Airlangga.

Rahayuningsih, I. 2013. Konflik Peran Ganda pada Tenaga Kerja Perempuan. Jurnal Psikosains, [e-journal] 5 (1): pp. 73-86.

Salim, E., Sri, M.A., Evi, N.A., Nizam, Alvin, P. 2015. Population Dynamics and Sustainable Development in Indonesia. Jakarta: UNFPA Indonesia.

Sukmana, G.M. 2013. Pengaruh Tingkat Pendidikan, Pengalaman Kerja, dan Pemberian Insentif Kerja terhadap Produktivitas Tenaga Kerja. Jurnal Ilmiah
Mahasiswa FEB Universitas Brawijaya, [ejournal] 1 (2).

Syaadah, N. 2014. Analisis Dampak Pertambahan Penduduk terhadap Penyerapan Angkatan Kerja. Jurnal Ilmiah Pendidikan Geografi, [e-journal] 2 (1).

Todaro, M.P., Smith, S.C. 2015. Economic Development. London: Pearson Education Limited.

Yusrini, B.A. 2017. Tenaga Kerja Wanita dalam Perspektif Gender di Nusa Tenggara Barat. Jurnal Al-Maiyyah, [e-journal] 10 (1): pp. 115-131.

WHO. 1947. Definisi Sehat WHO. [online] Available at: www.who.int. 